\title{
PENGEMBANGAN BUPENA BERBASIS PENDEKATAN STM (SAINS TEKNOLOGI MASYARAKAT) UNTUK MENINGKATKAN KEMAMPUAN PEMECAHAN MASALAH IPA
}

\author{
Hotma Tiolina Siregar, Rinci Simbolon \\ Surel: tiolinahotma@gmail.com
}

\begin{abstract}
This study aims to describe the results of increasing student problem solving abilities and learning tools in the form of an authentic assessment book (BUPENA) through the community technology science approach (STM), at SD Muhammadiyah 08 Medan, Class 4E, 2020-2021. The data collection tools in this study were validation sheets, problem-solving ability tests, and teacher and student response questionnaires developed through the Community Technology Science Approach (STM) with a modified 3-D model. The population in this study were all Class IV SD SD Muhammadiyah 08 Medan TA 2020-2021, the sample of this study was class IV-E, totaling 30 people. The Science and Technology Community (STM) approach using BUPENA developed in class IV-E SD Muhammadiyah 08 Medan has increased, which can be seen from: 19 students who completed the initial problem solving ability test were 19 people with an average score of 68.67 and increasing to 28 people with an average score of 87.83 on the final problem solving ability test. Then the completeness of classical learning for the initial problem solving ability test, there were $63.33 \%$ of students who did not complete and it increased to 93.33\% of students who completed the final problem solving ability test.
\end{abstract}

Keywords: BUPENA Development, STM Approach, IPA

\begin{abstract}
ABSTRAK
Penelitian ini bertujuan untuk Mendeskripsikan Hasil Peningkatan Kemampuan Pemecahan Masalah Siswa dan Perangkat Pembelajaran berupa Buku Penilaian Autentik (BUPENA) melalui Pendekatan Sains Teknologi Masyarakat (STM), di SD Muhammadiyah 08 Medan Kelas 4E TA 2020-2021. Alat pengumpulan data pada penelitian ini adalah lembar validasi, tes kemampuan pemecahan masalah, dan angket respon guru dan siswa yang dikembangkan melalui Pendekatan Sains Teknologi Masyarakat (STM) dengan model 3-D yang telah dimodifikasi. Populasi dalam penelitian ini adalah seluruh Kelas IV di SD SD Muhammadiyah 08 Medan TA 2020-2021, sample penelitian ini adalah kelas IV-E yang berjumlah 30 orang. Pendekatan Sains Teknologi Masyarakat (STM) menggunakan BUPENA yang dikembangkan di kelas IV-E SD Muhammadiyah 08 Medan mengalami peningkatan yang dapat dilihat dari: banyak siswa yang tuntas pada tes kemampuan awal pemecahan masalah ada 19 orang dengan nilai rata-rata 68,67 dan meningkat menjadi 28 orang dengan nilai rata-rata 87,83 pada tes kemampuan akhir pemecahan masalah. Lalu ketuntasan belajar klasikal untuk tes kemampuan awal pemecahan masalah terdapat $63,33 \%$ siswa yang tidak tuntas dan meningkat menjadi $93,33 \%$ siswa adalah tuntas pada tes kemampuan akhir pemecahan masalah.
\end{abstract}

Kata Kunci : Pengembangan BUPENA, Pendekatan STM, IPA 
Hotma Tiolina Siregar, Rinci Simbolon : Pengembangan Bupena ...

\section{PENDAHULUAN}

Pendidikan memegang peranan yang sangat penting dalam mencetak dan membangun generasi berkualitas. Penyelenggaraan pendidikan yang berkualitas merupakan investasi jangka panjang". Pada saat sekarang ini, kurikulum 2013 merupakan upaya pemerintah dalam memperbaiki sistem pendidikan di Indonesia. Dalam standar isi kurikulum 2013 dijelaskan bahwa dalam mata pelajaran IPA peserta didik diharapkan dapat menunjukkan sikap, logis, kritis, analitis, kreatif, cermat dan teliti, bertanggung jawab, responsif, dan tidak mudah menyerah dalam memecahkan masalah. Pendidikan IPA di Sekolah Dasar bertujuan agar siswa menguasai pengetahuan, konsep, prinsip, proses penemuan, serta memiliki sikap ilmiah, yang akan bermanfaat bagi siswa dalam mempelajari diri dan alam sekitar. Pendidikan IPA menekankan pada pemberian pengalaman langsung untuk mencari tahu dan berbuat sehingga mampu menjelajahi dan memahami alam sekitar secara ilmiah.

Tujuan utama penyajian BUPENA ini adalah untuk memberikan kemudahan bagi siswa untuk melaksanakan proses pembelajaran saintifik dan memungkinkan guru melakukan penilaian autentik. Besar harapan kami, siswa dapat mencapai kompetensi yang diharapkan dan guru dapat melaksanakan penilaian autentik terhadap siswa secara objektif.

Salah satunya adalah dengan perbaikan Buku Teks, Buku teks adalah buku pelajaran dalam bidang studi tertentu, yang merupakan buku standar, yang disusun oleh para pakar dalam bidang itu buat maksud-maksud dan tujuan instruksional, yang diperlengkapi dengan sarana-sarana pengajaran yang serasi dan mudah dipahami oleh pemakainya di sekolahsekolah.

Dalam proses perbaikan kemampuan pemecahan masalah IPA siswa, maka siswa harus banyak membacaa dan melihat fenomena disekitar lingkungan. Sehingga peneliti akan mengembangkan BUPENA. Hal ini ditunjukkan dari observasi yang dilakukan bahwa guru menggunakan BUPENA yang berisi latihan-latihan yang harus dikerjakan siswa dan tidak inovatif sehingga tidak menarik siswa untuk mempelajarinya dan penggunaan BUPENA dalam pembelajaran di sekolah masih terbatas, BUPENA yang digunakan belum memadai dengan syarat pembuatan BUPENA, dan BUPENA belum efektif.

BUPENA berisi rangkaian proses pembelajaran yang disajikan dalam urutan sesuai dengan buku teks pemerintah dengan mengakomodasi eksplorasi konsep, yakni berisi materi tambahan untuk mempertajam pemahaman siswa terhadap materi yang sedang dipelajari. Kemudian kegiatan, yang disajikan bervariasi yang meliputi kegiatan praktik, projek, atau portofolio.

Pendekatan STM (Sains Teknologi Masyarakat) adalah suatu usaha untuk menyajikan sains (IPA) melalui pemanfaatan masalah- 
masalah dalam kehidupan sehari-hari.

Pendekatan sains teknologi dan masyarakat melibatkan siswa dalam penentuan tujuan pembelajaran, prosedur pelaksanaan pembelajaran, pencarian informasi bahan pembelajaran dan bahkan pada evaluasi belajar. Tujuan utama pendekatan sains teknologi dan masyarakat (STM) yaitu agar dihasilkan siswa-siswa yang memiliki bekal ilmu dan pengetahuan agar nantinya mampu mengambil keputusan-keputusan terkait masalahmasalah dalam masyarakat.

Tujuan dari STM bagi guru/dosen adalah agar memahami kaitan antara sains teknologi masyarakat secara positif, serta dampaknya bagi kehidupan manusia. Sains teknologi masyarakat sangat berguna bagi siapa saja dalam menemukan sesuatu yang baru dalam kehidupan masyarakat. Dengan memperkenalkan STM kepada peserta didik, mereka akan memiliki kepekaan dan kesadaran yang sangat tinggi trehadap kehidupan mereka sendiri.

Kelebihan model STM adalah dapat meningkatkan literasi sains, perhatian terhadap interaksi sains, teknologi, dan masyarakat. Kelemahan model STM yaitu dalam pelaksanaan proses belajar mengajar di kelas memerlukan tambahan waktu jika dibandingkan dengan pembelajaran model konvensional.

Tujuan penelitian ini adalah Peningkatan kemampuan pemecahan masalah siswa, Membuat perangkat pembelajaran berupa BUPENA yang dikembangkan melalui pendekatan
Sains Teknologi Masyarakat.

\section{METODE PENELITIAN}

Penelitian ini mengharapkan dapat menghasilkan BUPENA yang valid, efektif, dan praktis yang dikembangkan melalui pendekatan Sains Teknologi Masyarakat (STM) dengan model 3-D yang telah dimodifikasi.

Peneliti melakukan wawancara kepada guru IPA yang mengajar di kelas IV SDS Muhammadiyah 08 Medan. Sekolah tersebut sudah menggunakan kurikulum 2013. Dan diperoleh kesimpulan bahwa BUPENA yang digunakan di sekolah terdiri atas beberapa tema dan beberapa mata pelajaran yang digabungkan dalam satu bupena.

Analisis yang dilakukan terhadap siswa kelas IV SDS Muhammadiyah 08 Medan meliputi perkembangan kognitif, kemampuan akademik, latar belakang pengetahuan, dan latar belakang sosial siswa.

Analisis konsep bertujuan untuk mengidentifikasi dan merinci bagianbagian utama pada materi yang akan dipelajari siswa kelas IV SDS Muhammadiyah 08 Medan sesuai dengan Kompetensi Dasar (KD) pada kurikulum 2013.

Memahami sifat-sifat bunyi dan keterkaitannya dengan indera pendengaran. Menyajikan laporan hasil pengamatan dan/atau percobaan tentang sifat-sifat bunyi.

Ketika menyusun tes kemampuan pemecahan masalah, maka terlebih dahulu menyusun kisi- 
Hotma Tiolina Siregar, Rinci Simbolon : Pengembangan Bupena ...

kisi tes kemampuan pemecahan masalah agar tes yang disusun dapat terukur, jelas, dan terarah. Media pembelajaran yang diperlukan dalam pelaksanaan pembelajaran matematika pada materi bunyi meliputi rencana pelaksanaan pembelajaran (RPP).

Format dalam pembuatan BUPENA adalah dengan memperhatikan syarat-syarat dan struktur dalam penyusunan BUPENA. Pembuatan BUPENA mengikuti syarat didaktik, syarat kontruksi, dan syarat teknik.

Pada tahap ini dihasilkan rancangan awal berupa RPP untuk empat kali pertemuan, BUPENA dengan tiga tema pada materi bunyi. Validasi para ahli difokuskan pada format, isi, ilustrasi, dan bahasa yang mencakup semua perangkat pembelajaran yang dikembangkan.

BUPENA yang telah dikembangkan valid berdasarkan kriteria kevalidan oleh penilaian ketiga validator, lalu diimplementasikan untuk mengetahui kelayakan BUPENA secara efektif.

Bahwa BUPENA yang digunakan di sekolah terdiri atas beberapa tema dan beberapa mata pelajaran yang digabungkan dalam satu bupena. BUPENA yang digunakan di sekolah sudah sesuai dengan kompetensi dasar dan tujuan pembelajaran, hanya saja materi pembelajaran IPA kurang luas dibahas.

Kemampuan akademik IPA sebagian siswa kelas IV SDS Muhammadiyah 08 Medan tergolong cukup baik yang dilihat dari hasil ulangan harian siswa. Namun siswa masih memiliki kemampuan yang sangat rendah dalam menemukan konsep dan memecahkan masalah karena siswa sering menghapal hal itu beresiko untuk siswa melupakan materi yang sedang dipelajarinya. Akan tetapi siswa sudah memiliki kelompok belajar di kelas. Namun sebagian siswa masih takut untuk mengemukakan pendapatnya dalam proses pembelajaran.

Analisis konsep dilaksanakan agar materi yang disajikan dalam penelitian tidak ada yang terlewatkan dan terlihat sistematis. Adapun materi yang akan dipelajari adalah Bunyi.

Pada Tahap Perancangan (Design), jika tidak dilakukan penyusunan tes, maka tes mengandung makna ambigu ataupun tes tidak valid karena tes hanya dituliskan tanpa ada batasan atau luas.

Media pembelajaran yang diperlukan dalam pelaksanaan pembelajaran matematika pada materi bunyi meliputi rencana pelaksanaan pembelajaran (RPP), laporan praktikum, BUPENA, Tes kemampuan pemecahan masalah, angket respon siswa, dan angket respon guru.

Lembar validasi para ahli, tes awal dan tes akhir dari kemampuan pemecahan masalah yang masingmasing terdiri atas tiga soal, angket respon siswa dan angket respon guru.

Perangkat pembelajaran hasil revisi yang telah dinyatakan valid oleh validator berdasarkan masukan dari para validator. Maka dari hasil hitung rata-rata penilaian validator diperoleh 
sebagai berikut: Bupena 4.84 valid, Angket Respon Siswa 4.79 valid, Angket Respon Guru 4.89 valid, Angket Respon Siswa 4.79, Tes Kemampuan Awal Pemecahan Masalah 4.72 valid, dan Tes Kemampuan Akhir Pemecahan Masalah 4.75.

Adapun hasil dari ketuntasan belajar siswa yang dilakukan dengan memberikan tes kemampuan awal pemecahan masalah dan tes kemampuan akhir pemecahan masalah di kelas IV-E yang diikuti sebanyak 30 orang.

- Ketuntasan belajar individu tes kemampuan awal pemecahan masalah 19 orang, Persentase ketuntasan klasikal 63,33\%, Kategori persentase Tidak Tuntas

- Ketuntasan belajar individu tes kemampuan akhir pemecahan masalah 28 orang, Persentase ketuntasan klasikal 93,33\%, Kategori persentase ketuntasan Tuntas

- Tes kemampuan awal pemecahan masalah adalah tidak tuntas karena ada 11 orang siswa yang nilainya < KKM (70) dan persentase ketuntasan klasikal < $85 \%$ yaitu $63,33 \%$. Sedangkan tes kemampuan akhir pemecahan masalah adalah tuntas karena 28 siswa lulus dengan nilai $\geq \mathrm{KKM}$ (70) dan persentase ketuntasan klasikal $\geq 85 \%$ yaitu $93,33 \%$.
Tes pemecahan masalah dilakukan dengan memberikan siswa tes kemampuan awal pemecahan masalah dan tes kemampuan akhir pemecahan masalah.

Analisis Ketercapaian Tujuan Pembelajaran Untuk Tes Kemampuan Awal Pemecahan Masalah yaitu :

- Memahami Masalah 56,67\% TPK Belum Tercapai

- Merencanakan Masalah 50\% TPK Belum Tercapai

- Melaksanakan Rencana Pemecahan Masalah 56,67\% TPK Belum Tercapai

- Memeriksa Kembali 46,67\% TPK Belum Tercapai

Analisis Ketercapaian Tujuan Pembelajaran Untuk Tes Kemampuan Akhir Pemecahan Masalah yaitu :

- Memahami Masalah 100\% TPK Tercapai

- Merencanakan Masalah 93,33\% TPK Tercapai

- Melaksanakan Rencana Pemecahan Masalah 96,67\% TPK Tercapai

- Memeriksa Kembali 100\% TPK Tercapai

Untuk Tes Kemampuan Awal Pemecahan Masalah yaitu diperoleh rata-rata $70 \%$ sehingga TPK belum tercapai sedangkan Untuk Tes Kemampuan Akhir Pemecahan Masalah di diperoleh rata-rata 91,11\% maka TPK Tercapai. Sehingga tes kemampuan akhir pemecahan masalah yang mencapai 
Hotma Tiolina Siregar, Rinci Simbolon : Pengembangan Bupena ...

indikator dari pemecahan masalah tersebut dengan tujuan pembelajaran yang sudah mencapai $\geq 75 \%$ tujuan pembelajaran yaitu $91,11 \%$ dan dirumuskan dapat dicapai oleh $65 \%$ siswa yang tuntas sehingga TPK tercapai.

Dari hasil jawaban atau pendapat siswa dan guru yang terdapat dalam angket respon siswa dan angket respon guru diperoleh rincian sebagai berikut:

- Angket Respon Siswa $\geq 80 \%$ dari 30 orang responden dengan 12 kuesioner diangket Sangat Positif

- Angket Respon Guru $\geq 80 \%$ dari 1 orang responden dengan 12 kuesioner diangket Sangat Positif

Hasil pencapaian waktu pembelajaran dalam uji coba dengan 4 kali pertemuan atau 8JP x 40 menit. Jika dibandingkan dengan waktu pembelajaran biasa tidak terdapat perbedaan yang signifikan terhadap pencapaian waktu dengan pembelajaran yang menggunakan BUPENA matematika berbasis pendekatan STM. Kriteria efektif jika waktu pembelajaran tidak melebihi waktu pembelajaran biasa. Berdasarkan analisis data uji coba, waktu pembelajaran yang digunakan sama dengan waktu pembelajaran biasa di sekolah tempat penelitian dan juga sesuai dengan waktu di dalam RPP. Oleh karena itu, BUPENA yang dikembangkan telah efektif dalam indikator keefektifan pencapaian waktu pembelajaran.

Hasil dari tes kemampuan awal pemecahan masalah dan tes kemampuan akhir pemecahan masalah di kelas IV-E yang diikuti sebanyak 30 orang.

Analisis Data Tes Kemampuan Pemecahan Masalah maka diperoleh :

- Hasil rata-rata tes kemampuan awal pemecahan masalah 68,67

- Hasil rata-rata tes kemampuan akhir pemecahan masalah 87,83

- Hasil rata-rata N-gain 0,68

- Kategori peningkatan dari N-gain maka kategori Sedang

Adapun hasil analisis yang menyatakan bahwa BUPENA praktis adalah sebagai berikut:

- BUPENA dengan menggunakan pendekatan sains teknologi masyarakat (STM) pada materi bunyi dikatakan praktis karena berdasarkan penilaian validator terhadap BUPENA adalah valid, sehingga BUPENA dapat digunakan dengan sedikit atau tanpa revisi.

- Berdasarkan hasil pengamatan terhadap penggunaan BUPENA di kelas maka BUPENA dikatakan praktis karena siswa sangat aktif dalam mengerjakan seluruh tes dan percobaan yang ada di dalam BUPENA dengan benar dan sesuai waktu yang disediakan.

- Dilihat dari hasil hitung angket respon siswa adalah $\geq 80 \%$ dari banyaknya responden terhadap setiap kuesioner sehingga BUPENA dikatakan praktis karena respon guru dan siswa adalah sangat positif terhadap BUPENA yang dikembangkan. 
BUPENA yang dikembangkan efektif karena memenuhi kriteria penilaian yaitu tuntas, tercapai, efektif, dan positif sesuai dengan aspek efektifnya. Data Keefektifan BUPENA adalah :

- Ketuntasan belajar individu dari tes kemampuan awal pemecahan masalah 19 orang tuntas, dan 11 orang tidak tuntas

- Ketuntasan belajar individu dari tes kemampuan akhir pemecahan masalah 28 orang tuntas, dan 2 orang tidak tuntas

- Ketuntasan belajar klasikal dari tes kemampuan awal pemecahan masalah 63,33\% (Tidak tuntas)
- Ketuntasan belajar klasikal dari tes kemampuan akhir pemecahan masalah 93,33\%(Tuntas)

- Rata-rata persentase pencapaian tujuan pembelajaran pada tes kemampuan awal pemecahan masalah $70 \%$ (TPK belum tercapai)

- Rata-rata persentase pencapaian tujuan pembelajaran pada tes kemampuan akhir pemecahan masalah 91,11\%(TPK tercapai)

- Analisis angket respon siswa Positif

- Analisis angket respon guru Positif

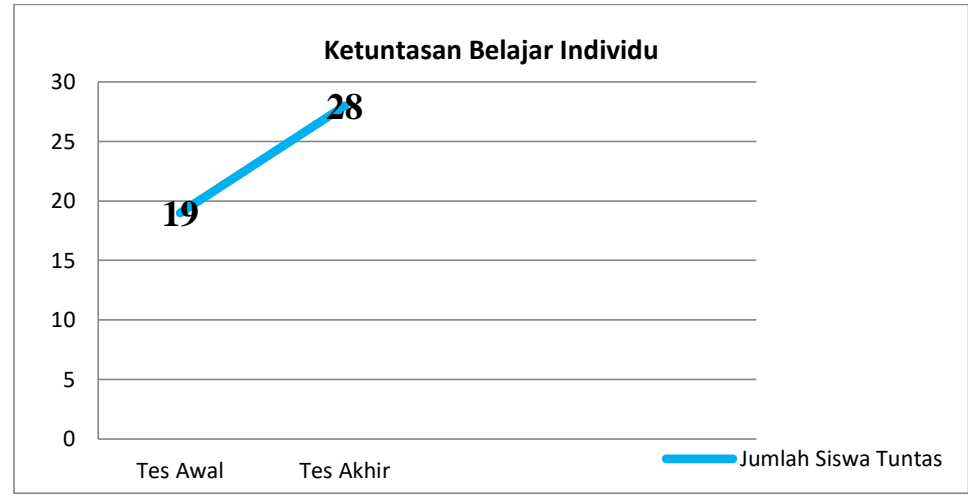

Gambar 1. Grafik Nilai Ketuntasan Belajar Individu

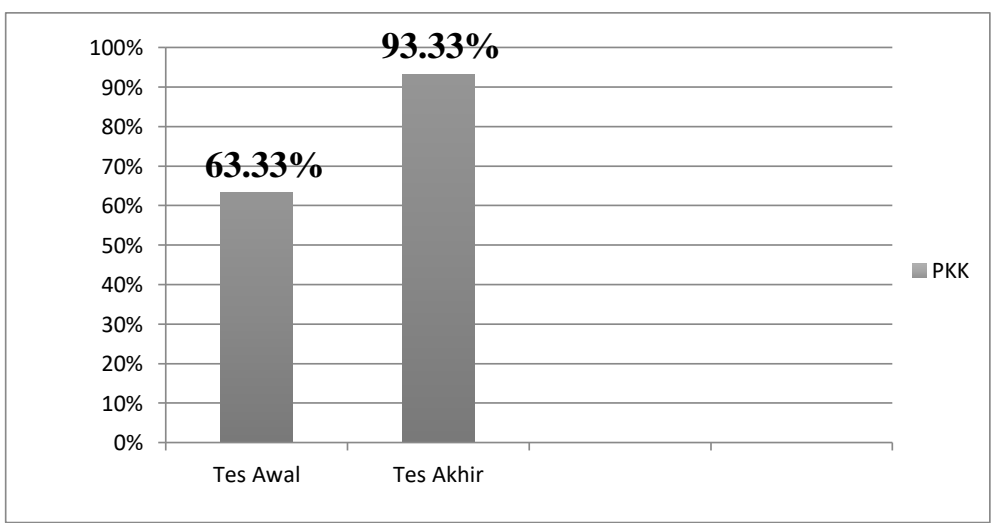

Gambar 2. Diagram Nilai Persentase Ketuntasan Belajar Klasikal 
Hotma Tiolina Siregar, Rinci Simbolon : Pengembangan Bupena ...

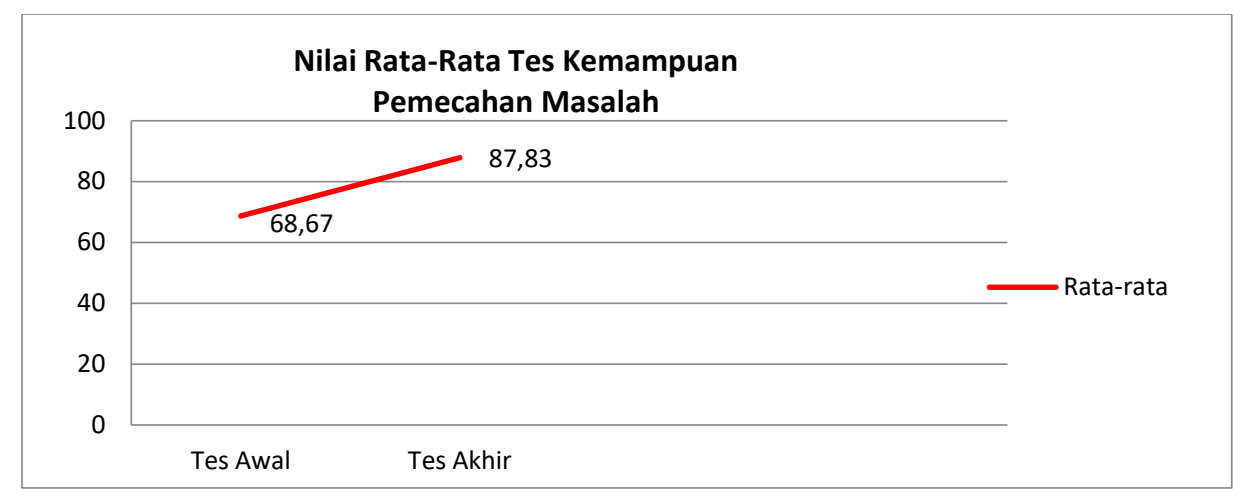

\section{Gambar 3. Grafik Nilai Rata-Rata Tes Kemampuan Pemecahan Masalah Matematis Siswa}

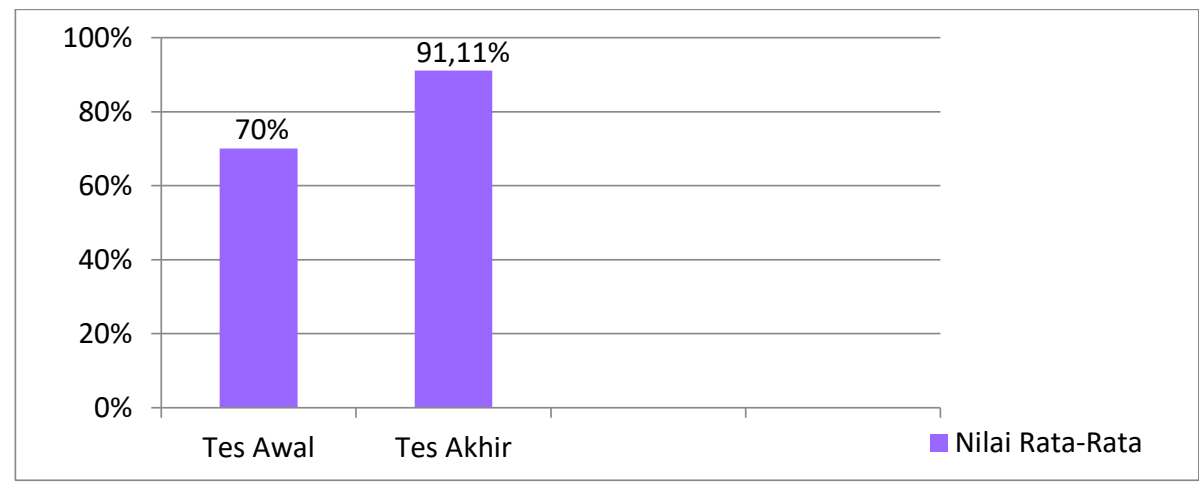

Gambar 4. Diagram Nilai Rata-Rata Persentase Pencapaian Tujuan Pembelajaran

\section{SIMPULAN}

Berdasarkan hasil penelitian dan pembahasan diperoleh kesimpulan sebagai berikut: Kemampuan pemecahan masalah matematis siswa yang diberi pembelajaran pendekatan sains teknologi masyarakat (STM) menggunakan BUPENA yang dikembangkan di kelas IV-E SDS Muhammadiyah 08 Medan mengalami peningkatan yang dapat dilihat dari: banyak siswa yang tuntas pada tes kemampuan awal pemecahan masalah ada 19 orang dengan nilai rata-rata 68,67 dan meningkat menjadi 28 orang dengan nilai rata-rata 87,83 pada tes kemampuan akhir pemecahan masalah. Lalu ketuntasan belajar klasikal untuk tes kemampuan awal pemecahan masalah terdapat $63,33 \%$ siswa yang tidak tuntas dan meningkat menjadi 93,33\% siswa adalah tuntas pada tes kemampuan akhir pemecahan masalah. Keefektifan perangkat pembelajaran berupa BUPENA yang dikembangkan melalui pendekatan sains teknologi masyarakat (STM) untuk meningkatkan kemampuan pemecahan masalah matematis siswa di kelas IV-E SDS Muhammadiyah 08 Medan diperoleh melalui tes kemampuan awal pemecahan masalah 
dan tes kemampuan akhir pemecahan masalah. Adapun tes kemampuan awal pemecahan masalah yang dilakukan untuk menilai keefektifan BUPENA yang telah dikembangkan dikatakan efektif pada angket respon siswa dan waktu pembelajaran. Sedangkan pada tes kemampuan akhir pemecahan masalah diperoleh hasil efektif yaitu: (1) ketuntasan belajar klasikal, (2) ketercapaian tujuan pembelajaran, (3) angket respon siswa, dan (4) waktu pembelajaran. Dapat dilihat pada tes kemampuan akhir pemecahan masalah syarat keefektifan BUPENA yang dikembangkan telah terpenuhi, sehingga dapat disimpulkan bahwa BUPENA yang telah dikembangkan melalui pendekatan sains teknologi masyarakat (STM) telah efektif digunakan.

\section{DAFTAR RUJUKAN}

Ahmad Susanto. 2016. Teori Belajar dan Pembelajaran di Sekolah Dasar. Jakarta: Kencana

Anitah, Sri, dkk. 2014. Strategi Pembelajaran di SD. Jakarta: Universitas Terbuka.

Basir, Muhammad. 2017. Pendekatan Pembelajaran. Sulawesi Selatan: Lampena Intimedia.

Gunawan, Muhammad Ali. 2013. Statistik Penelitian Pendidikan. Yogyakarta: Parama Publishing.

Nurdyansyah, dkk. 2016. Inovasi Model Pembelajaran Sesuai Kurikulum 2013. Sidoarjo: Nizamia Learning Center.

Prahmana, Rully. 2017. Design Research (Teori dan
Implementasinya: Suatu

Pengantar). Depok: Raja Grafindo Persada.

Poedjadi, Anna. 2010. Sains Teknologi Masyarakat. Jakarta: Rosda

Salirawati, D. 2014. Penyusunan dan Kegunaan LKS dalam Proses Pembelajaran.

(http://staff.uny.ac.id/sites/default /files/pengabdian/das-salirawatimsi-dr/19penyusunan-dankegunaan-lks.pdf). [Diakses 10 Februari 2019).

Sanjaya, Wina. 2014. Strategi Pembelajaran Berorientasi Standar Proses Pendidikan. Jakarta: Kencana.

Slameto. 2013. Belajar dan FaktorFaktor yang Mempengaruhinya. Jakarta: Rhineka Cipta.

Sudjana. 2017. Metoda Statistika. Bandung: Tarsito Bandung Sugiyono. 2016. Metode Penelitian Pendidikan (Pendekatan Kuantitatif, Kualitatif, dan $R$ \& D). Bandung: Alfabeta.

Tawil, Muh dkk. 2013. Berpikir Kompleks dan Implementasinya dalam Pembelajaran IPA. Makassar: Universitas Negeri Makassar.

Trianto. 2011. Mendesain Model Pembelajaran Inovatif-Progresif. Jakarta: Kencana. 